\title{
The Metacognitive Deficits in Middle Schools in Athens
}

\author{
Tryfon Mavropalias, ${ }^{1}$ Charoula Andronidi ${ }^{2}$ \\ ${ }^{1}$ School of Education, Department of Primary Education, University of Western Macedonia \\ Florina, Greece \\ ${ }^{2}$ Philologist, Athens, Greece
}

*Corresponding Author: Dr. Tryfon Mavropalias, Department of Primary Education, University of Western Macedonia, Greece

Received Date: 02-07-2017

Accepted Date: 08-07-2017

Published Date: 10-07-217

\begin{abstract}
The purpose of this paper is to investigate the views of middle school teachers in Athens, Greece, regarding the metacognitive deficits (MD) of students with learning disabilities (LD). Quantitative research was conducted using a questionnaire. Taking part in the study were 183 educators from the middle schools of Eastern Athens. From the findings, it was deduced that most educators, although they appreciate the importance of recognizing $L D$, do not have sufficient knowledge to detect $L D$ among their students. Additionally, the extent to which they use specialized teaching methods to teach students with metacognitive deficits or to assess the effectiveness of their intervention is limited. The main obstacles, according to educators, are their limited training on the topic of metacognitive deficits and their lack of teaching time.
\end{abstract}

Keywords: Metacognitive deficits, teaching strategies, middle school educators, training

\section{INTRODUCTION}

Special learning difficulties are learning difficulties that have a number of dimensions, appear in various combinations and forms, and significantly affect the school performance of students. The diagnostic manual DSM-IV recognizes four categories of disorders: disorders in reading, in arithmetic, and in writing and disorders that fail to be defined otherwise. In the revised version of DSM-IV (DSM-V), it is emphasized that special learning difficulties appear during assessments in three different sectors: reading, writing, and mathematics. Additionally, the IQ-success divergence and its substitutions are underlined by four criteria. The first criterion is related to the basic attributes of learning difficulties. Specifically, the child should manifest one of the six symptoms for at least six months, despite being provided with assistance. The second criterion is related to the assessment of the characteristics that affect academic progress, the treatment of the student by professional educators, and the whole spectrum of daily life. The third criterion pertains to the age when the symptoms appear. Finally, the fourth criterion states that certain disorders (mental disability, acoustic or visual acuity, and other mental or neurological disorders) and cultural factors must be listed before the diagnosis of special learning difficulties is confirmed (Tannock, 2014).

The process of metacognition entails the effective use of strategies, the active monitoring of the progress of a plan, and the contemplation of its results (Panteliadou, 2011). Metacognition consists of the knowledge regarding one's work, one's aims, and the learning methods related to those experiences. It functions as a reference point for the interpretation and also the explanation of cognitive actions that students do during the process of working on a cognitive project. According to Salvaras (2013), metacognition is the "knowledge of an action (what will happen, how, why, how frequently), self-monitoring by the student while he or she is executing an action, criteria for the implementation of adjustments, the expression of metacognitive experiences, and contemplation of results" (p. 37-38).

In other words, metacognition is what allows the child to be aware of the way that the knowledge machine works, aware of cognitive processes, and able to predict, program, direct, and assess his or her own thoughts. In this way, metacognition allows the child to realize that he 
or she is thinking via certain procedures and it provides the child with knowledge about how these procedures work (Polychronopoulou, 2012).

Specifically, a child with metacognition is aware of what the existing knowledge is, whether it is adequate to face a certain problem, whether adjustments need to be made, what kind of planning and strategizing are required to solve it, and whether the sequence of strategies to be applied will lead to the desired result (Polychronopoulou, 2012, p. 593).

Students are deemed efficient if they are able to use the appropriate strategies to complete a cognitive task. Children with special difficulties manifest deficits in the metacognition section. Research data indicates that the abovementioned deficits are important and affect all cognitive tasks throughout the children's entire school life. Students facing special learning difficulties are unable to use the appropriate strategies. Metacognitive strategies include planning, watching and adjusting a task (Pintrich, 1999). How effectively a student learns is defined by the use of the right cognitive and metacognitive strategies (National Research Council, 1998). In particular, it is defined by whether the difficulties they face are related either to the selection or the implementation of strategies and are an outcome of metacognitive knowledge. This implies that students can realize the value of the use of strategies or of taught knowledge, while not being aware of where, how, and why they can use the appropriate strategies or knowledge. Students with learning difficulties, therefore, use fewer and simpler strategies in comparison to their typical peers (Botsas \& Padeliadu, 2003).

Educators in secondary education recognize the catalytic role the implementation of metacognitive strategies plays, as metacognitive strategies equip students with a series of skills that allow them to plan, watch, and adjust learning procedures in all knowledge subjects as well all sections of their life (Garmabi \& Zareian, 2016; Rama, 2011; Weaver, 2012).

Given this, and that students cannot realize the importance of cognitive and metacognitive strategies on their own, educators recognize the teaching of these strategies as especially important. Educators believe that it is important to incorporate the teaching of metacognitive strategies in a systematic way during learning procedures, as they believe it is important to help their students practice these strategies
(Swanson, Cooney, \& McNamara, 2004). In addition to all this, several findings need to be noted. According to the opinions of educators, time needs to be allocated to students such that they can ponder each strategy they are taught, allowing them to understand how, when, and why it is used. Another point that is brought up by educators is the need for teaching various strategies, as they admit that each student has a different way of learning and transfers the process through a number of different experiences from his or her previous learning environments. Consequently, all strategies are not equally effective for all students (Garmabi \& Zareian, 2016; Rama, 2011; Weaver, 2012; Carr \& Kirtz, 1991).

\section{The Legal Framework of Learning Disabilitities in Greece}

In Greece, the diagnosis of a student with LD is conducted by the Centers for Diagnosis, $\mathrm{s}$ Diagnosis and Support (KEDDY) and, when it is deemed necessary, the students attend special classes. In parallel, an Individualized Education Program (IEP) is provided based on the needs of the child (Law 3699/2008, Special education and education of people with disability or special educational needs).

The weighted reading and writing tests that are deployed in Greece are limited. In general, the diagnosis process is hurdled by the lack of appropriate tools. In many cases, improvised tests whose validity is uncertain are designed by interdisciplinary scientific teams. Consequently, the responsible diagnostic services are unable to present a full picture of the child with learning difficulties and they are restricted to general and safe evidence. In conjunction with increased bureaucracy, further hurdles arise in the assessment process conducted by KEDDY (Anastasiou, 2008; Panteliadou \& Botsas, 2007).

\section{METHOD}

This quantitative study was conducted during the school year 2015-2016, with 183 secondary education educators participating in the survey. The aim of this project is the investigation of opinions of educators in secondary education concerning the metacognitive deficits of students with learning difficulties across all middle schools in Athens. Specifically, the methods used by educators to deal with metacognitive deficits will be examined as well as the ways students are assessed, based on the way they are treated by their educators, according to their educators' beliefs. The questions to be investigated are the following: 
> How many secondary education educators possess the skill to assess the level of metacognitive deficits of students with learning disabilities?

What methods do secondary education educators use to deal with metacognitive deficit cases among students with learning difficulties and what is their degree of effectiveness?

How much do secondary education educators assess the amount of metacognitive skill students with learning difficulties gained after the implementation of different teaching methods?

\section{Participants}

The participants in the survey were 183 middle school educators (grades 7-9) with students with learning difficulties (LD) in their classes from 14 middle schools in Eastern Athens, Attica (23\% of the 60 regional daily middle schools). We selected this region of Athens as we had access to local education authorities (school principals, school advisors, etc.). The questionnaire was sent to 285 educators. However, only 183 returned completed questionnaires, or $64.2 \%$ of the invited sample. Of the 183 participants, $67(36.6 \%)$ educators were men and $116(63.4 \%)$ were women. Of these, $158(86.3 \%)$ had bachelor's degrees, 12 (6.6\%) had master's degrees, $11(6 \%)$ had master's degrees in special education, and 2 $(1.1 \%)$ had PhDs.

\section{Data Source}

The teachers were asked to complete a questionnaire consisting of three sections. In the first section, teachers were asked to provide personal demographic information as well as details on their education, work status, and experience. In the second section, special education teachers (SETs) were asked about metacognitive deficit issues (understanding of the term metacognitive, training of teachers, and assessment of students with metacognitive deficits). In the third section, educators were asked about their method of teaching (individualized teaching, teaching techniques for enhancing metacognition, and issues regarding the analytical teaching program) on a five-point Likert scale with response anchors $(1=$ very little, $2=$ a little, $3=$ moderately, $4=$ quite a bit, $5=$ very much). They were also asked about their professional preparation for working with students with learning difficulties.

\section{FINDINGS}

\section{Characteristics of Teachers}

Demographics. Table 1 shows the characteristics of participants according to their age and years of teaching service.

Table1. Description of Participants According to their Age and Years of Teaching Service

\begin{tabular}{|l|l|l|l|l|}
\hline Variable & $\mathrm{N}$ & Mean & SD & Range \\
\hline Age & 183 & 46.42 & 6.37 & $26-61$ \\
\hline $\begin{array}{l}\text { Years of service } \\
\text { in education }\end{array}$ & 183 & 16.9 & 1.92 & $0.5-28$ \\
\hline
\end{tabular}

It is noted that the vast majority of the teachers $(\mathrm{N}=147,80.3 \%)$ had a permanent position and $36(19.7 \%)$ had a temporary position.

Training in LD. Of the 183 educators, 101 (55.2\%) declared that they have been trained in learning difficulty or metacognitive difficulty issues, while $82(44.8 \%)$ have not been trained at all. Of the 101 educators who were trained, 56 $(55.0 \%)$ were trained in seminars lasting less than 40 hours.

Table 2 shows the opinions of educators regarding their training in $\mathrm{LD}$, their readiness to teach students with LD, and the degree to which they understand the term metacognitive deficits.

Table2. Description of Participants According to their Training, Readiness, and Knowledge of the Term "Metacognitive Deficits"

\begin{tabular}{|l|l|l|l|l|}
\hline Variable & $\mathrm{N}$ & Mean & SD & Range \\
\hline Training adequacy & 183 & 2.46 & 0.99 & $1-5$ \\
\hline $\begin{array}{l}\text { Readiness to teach } \\
\text { students with LD }\end{array}$ & 183 & 2.23 & 0.96 & $2-5$ \\
\hline $\begin{array}{l}\text { Knowledge of the } \\
\text { term metacognitive } \\
\text { deficits }\end{array}$ & 183 & 2.40 & 1.06 & $1-5$ \\
\hline
\end{tabular}

\section{Characteristics of Students}

Table 3 shows the average age and number of students with LD per class and the average size of classes containing students with LD.

Table3. Number of Students with LD, Age of Students, and Class Size

\begin{tabular}{|l|l|l|l|l|}
\hline Variable & $\mathrm{N}$ & Mean & SD & Range \\
\hline $\begin{array}{l}\text { Age of students with } \\
\text { LD }\end{array}$ & 384 & 14.3 & 1.67 & $13-16$ \\
\hline $\begin{array}{l}\text { Class size for students } \\
\text { with LD }\end{array}$ & 384 & 22.8 & 2.06 & $17-27$ \\
\hline $\begin{array}{l}\text { Students with LD in } \\
\text { class }\end{array}$ & 384 & 2.2 & 0.84 & $1-4$ \\
\hline
\end{tabular}

Of 384 students with LD, 161 (41.9\%) are in general classes, without additional support, while $16(4.0 \%)$ participate in a co-teaching program. The remaining $207(54.0 \%)$ are in special classes. 
With regard to seating arrangements, the sample declared only two types. Of 164 participants (nineteen teachers were missing data), 146 (89\%) arranged the students' desks in rows, the traditional Greek way, and 18 (11\%) teachers

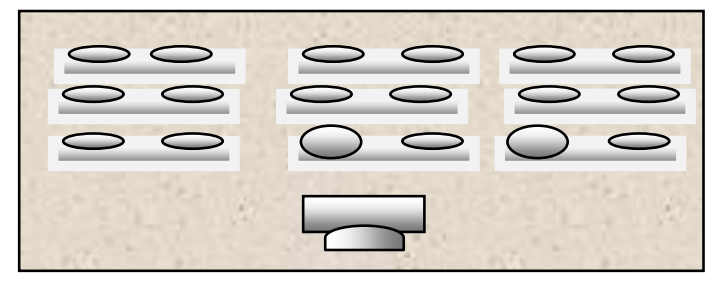

Traditional stated that desks were typically placed in the shape of the Greek letter $p i$, or a horseshoe (Mavropalias \& Anastasiou, 2016, p. 230). Furthermore, according to the position of students with LD, most educators place them in close proximity to their own seats (Figure 2).

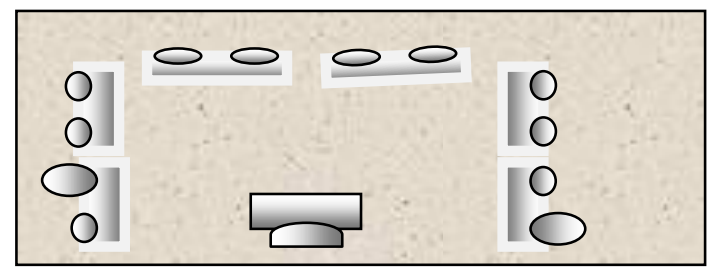

П [Greek letter pi or horseshoe]

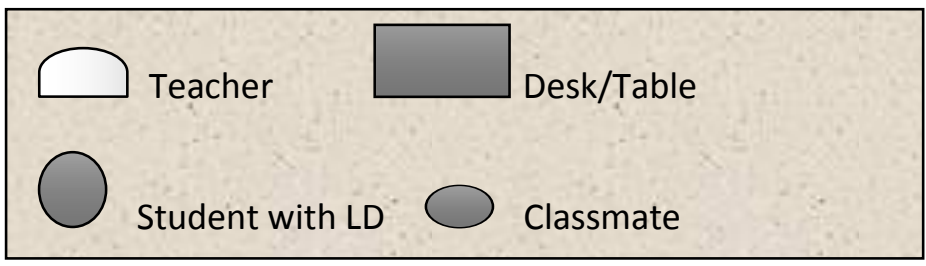

Figure 2.Classroom Seating Arrangements

From the participants' responses it is deduced that a significant percentage, $67.8 \%(\mathrm{~N}=124)$, have implemented individualized or differentiated teaching in their classrooms, while 27.9\% ( $\mathrm{N}=51)$ have not implemented this type of teaching. Finally, it is observed that a small percentage of the sample, $4.3 \%(\mathrm{~N}=8)$, seems to be unaware of these terms.

\section{MetacogNitive DeFicit ISSUES}

\section{Detection of Metacognitive Deficits}

Regarding the capability of educators to detect metacognitive deficits of their students in relation to the highest education title they possess, a statistical confidence interval was derived from the analysis $\left(x^{2}=23.135, d f=8, p\right.$ $<0.05)$. A clear majority $(76 \%)$ of educators with master's and $\mathrm{PhD}$ degrees answered "quite a bit" and "very much" concerning the detection of metacognitive deficits, while only $44 \%$ of educators with bachelor's degrees provided the same answer.

\section{Implementation of Metacognitive Strategies}

From their responses it is observed that of 164 $(89.6 \%)$ of educators who answered the survey $(\mathrm{N}=19,10.4 \%$, missing), most $(\mathrm{N}=104,63.0 \%)$ implement those strategies "a little."

\section{Assessment of Metacognitive Deficits}

From the sample's answers ( $\mathrm{N}=178,5$ missing) it is deduced that most educators $(\mathrm{N}=142$, $79.7 \%$ ) answered with "quite a bit" or "very much" regarding the importance of assessing metacognitive deficits among students with LD.

Table 4shows that the correlation between whether educators have been trained on the subject of LD and metacognitive deficits and their responses to these questions: (1) whether inadequate assessment of metacognitive deficits among students with learning difficulties may contribute to the increase of the difficulties students face, (2) whether middle school educators assess the level of metacognitive deficits in a systematic way, (3) how often educators assess the level off metacognitive deficits, (4) whether educators have the required knowledge to assess metacognitive deficits. As the frequencies in the first column are low, the $\chi^{2}$ test statistics and statistical significance shows values after the collapse and recoding of the first response anchor. From the answers, it is concluded that in general educators with or without training have similar attitude regarding the assessment of metacognitive deficits. There is a variation in the fact that most trained educators $(50.8 \%)$ assess metacognitive difficulties with a "moderate" frequency, while most educators without training (49.4\%) declared that they assess metacognitive difficulties "a little." On a similar note, $43.6 \%$ of educators with training declared, given their linguistic competencies, that they were "moderately" or "a little" prepared to assess learning difficulties. Respectively, the percentages for educators who have not been trained were $6.1 \%$ for "moderately" prepared and $65.0 \%$ for "a little" prepared. 
Table4. Correlation of Training with Concepts of Educators Concerning the Assessment of Metacognitive Deficits

\begin{tabular}{|c|c|c|c|c|c|c|}
\hline Training & \begin{tabular}{|c|} 
Very \\
Little
\end{tabular} & \begin{tabular}{|l} 
A \\
little
\end{tabular} & \begin{tabular}{|l} 
Moderat \\
ely
\end{tabular} & \begin{tabular}{|l|}
$\begin{array}{l}\text { Quite } \\
\text { a bit }\end{array}$ \\
4
\end{tabular} & \begin{tabular}{|l|}
$\begin{array}{l}\text { Very } \\
\text { Much }\end{array}$ \\
5
\end{tabular} & $\begin{array}{l}\chi^{2} \text {-test } \\
\text { statisti }\end{array}$ \\
\hline & $\begin{array}{l}\text { Inadec } \\
\text { deficit } \\
\text { learnir }\end{array}$ & $\begin{array}{l}\text { quate as } \\
\text { s may } \\
\text { g diffi }\end{array}$ & $\begin{array}{l}\text { ssessment } \\
\text { contribute } \\
\text { culties. }\end{array}$ & $\begin{array}{l}\text { of meta } \\
\text { to the } i\end{array}$ & $\begin{array}{l}\text { acognit } \\
\text { increas }\end{array}$ & $\begin{array}{l}\text { tive } \\
\text { se of }\end{array}$ \\
\hline $\begin{array}{l}\mathrm{YES}(\mathrm{N}=1 \\
01) \\
\mathrm{NO} \\
(\mathrm{N}=82)\end{array}$ & $\begin{array}{c}0 \\
(0 \%) \\
0 \\
(0 \%)\end{array}$ & $\begin{array}{c}7 \\
(6.9 \% \\
) \\
5 \\
(6.2 \% \\
)\end{array}$ & $\left|\begin{array}{c}6(5.9 \%) \\
11 \\
(13.6 \%)\end{array}\right|$ & \begin{tabular}{|c|}
51 \\
$(50.5$ \\
$\%)$ \\
31 \\
$(37.6$ \\
$\%)$ \\
\end{tabular} & $\begin{array}{c}37 \\
(36.6 \\
\%) \\
35 \\
(42.5 \\
\%)\end{array}$ & $\begin{array}{l}\chi^{2}= \\
20.710 \\
\\
d f=3, \\
p \\
0.001\end{array}$ \\
\hline & $\begin{array}{l}\text { Degre } \\
\text { metac }\end{array}$ & $\begin{array}{l}\text { e of sys } \\
\text { ognitiv }\end{array}$ & $\begin{array}{l}\text { stematic as } \\
\text { e deficits. }\end{array}$ & ssessme & ent of & \\
\hline $\begin{array}{l}\mathrm{YES}(\mathrm{N}=1 \\
01) \\
\mathrm{NO} \\
(\mathrm{N}=82)\end{array}$ & $\begin{array}{c}15 \\
(14.8 \\
\%) \\
19 \\
(23.1 \\
\%)\end{array}$ & $\begin{array}{l}23 \\
(22.8 \\
\%) \\
21 \\
(25.6 \\
\%)\end{array}$ & \begin{tabular}{|l|}
56 \\
$(55.4 \%)$ \\
39 \\
$(47.6 \%)$
\end{tabular} & \begin{tabular}{|l|}
4 \\
$(3.9 \%$ \\
3 \\
$(3.7 \%$ \\
\end{tabular} & \begin{tabular}{|l|}
3 \\
$(2.9 \%$ \\
0 \\
0 \\
$(0 \%)$
\end{tabular} & \begin{tabular}{|l}
$\chi^{2}$ \\
37.688 \\
\\
$d f=3$, \\
$p$ \\
0.001
\end{tabular} \\
\hline & $\begin{array}{l}\text { Freque } \\
\text { metac }\end{array}$ & $\begin{array}{l}\text { ency of } \\
\text { ognitiv }\end{array}$ & $\begin{array}{l}\text { assessmer } \\
\text { e deficits }\end{array}$ & & & \\
\hline $\begin{array}{l}\mathrm{YES}(\mathrm{N}=1 \\
01) \\
\mathrm{NO} \\
(\mathrm{N}=82)\end{array}$ & $\begin{array}{c}5 \\
(4.5 \% \\
) \\
6 \\
(7.3 \% \\
)\end{array}$ & $\begin{array}{c}14 \\
(13.9 \\
\%) \\
40 \\
(49.4 \\
\%)\end{array}$ & \begin{tabular}{|c|}
51 \\
$(50.8 \%)$ \\
29 \\
$(34.3 \%)$
\end{tabular} & \begin{tabular}{|c|}
25 \\
$(25 \%)$ \\
7 \\
$(9 \%)$
\end{tabular} & \begin{tabular}{|c|}
6 \\
$(5.7 \%$ \\
) \\
0 \\
$(0 \%)$
\end{tabular} & $\begin{array}{l}\chi^{2}= \\
22.018 \\
d f=4, \\
p \quad< \\
0.001\end{array}$ \\
\hline & $\begin{array}{l}\text { Know } \\
\text { readin }\end{array}$ & $\begin{array}{l}\text { ledge a } \\
\text { g meta }\end{array}$ & $\begin{array}{l}\text { dequacy o } \\
\text { cognitive }\end{array}$ & $\begin{array}{l}\text { of educa } \\
\text { deficits }\end{array}$ & ators & \\
\hline $\begin{array}{l}\mathrm{YES}(\mathrm{N}=1 \\
01) \\
\mathrm{NO} \\
(\mathrm{N}=82)\end{array}$ & $\begin{array}{c}19 \\
(18.6 \\
\%) \\
23 \\
(27.2 \\
\%)\end{array}$ & $\begin{array}{c}35 \\
(34.9 \\
\%) \\
53 \\
(65 \%)\end{array}$ & $\begin{array}{c}44 \\
(43.6 \%) \\
5(6.1 \%)\end{array}$ & $\begin{array}{c}3 \\
(2.9 \% \\
) \\
1 \\
(1.7 \% \\
)\end{array}$ & $\begin{array}{c}0 \\
(0 \%) \\
0 \\
(0 \%)\end{array}$ & $\begin{array}{l}\chi^{2}= \\
63.457 \\
d f=3, \\
p \\
0.001\end{array}$ \\
\hline
\end{tabular}

Out of 181 educators who answered (there were 2 missing data), $128(71.2 \%)$ answered that they consult their school advisor or psychologist when they detect that a student systematically manifests low performance in the subject of Language. Furthermore, 132 (68.3\%) declared that they update their family to take necessary actions. Additionally, 88 (48.9\%) declared that they seek advice from some more experienced colleague that has knowledge of special education. Moreover, 85 (47\%) stated that they change teaching methods and teaching aims based on the needs of the student they wish to support. The most-preferred actions of teachers are presented in Table 5.
Table5. The First Three Actions of Educators to Address Metacognitive Deficits

\begin{tabular}{|c|c|c|c|c|}
\hline Actions & $\begin{array}{c}\# 1 \\
\text { action } \\
(\mathrm{N}=181)\end{array}$ & $\begin{array}{c}\# 2 \\
\text { action } \\
(\mathrm{N}=179)\end{array}$ & $\begin{array}{c}\# 3 \\
\text { action } \\
(\mathrm{N}=179)\end{array}$ & 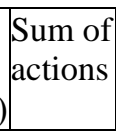 \\
\hline $\begin{array}{l}\text { Meetings or } \\
\text { discussions with } \\
\text { school advisor } \\
\text { /psychologist }\end{array}$ & \begin{tabular}{c|}
42 \\
$23.2 \%$
\end{tabular} & $\begin{array}{c}61 \\
34.1 \%\end{array}$ & \begin{tabular}{|c|}
25 \\
$13.9 \%$
\end{tabular} & $\begin{array}{c}128 \\
71.2 \%\end{array}$ \\
\hline $\begin{array}{l}\text { Informing the } \\
\text { student's family } \\
\text { so that they can } \\
\text { take initiatives }\end{array}$ & $\begin{array}{c}44 \\
26.5 \%\end{array}$ & $\begin{array}{c}53 \\
29.6 \%\end{array}$ & $\begin{array}{c}22 \\
12.2 \%\end{array}$ & $\begin{array}{c}119 \\
68.3 \%\end{array}$ \\
\hline \begin{tabular}{|l|} 
Seeking advice \\
from an \\
experienced \\
colleague with \\
special education \\
knowledge \\
\end{tabular} & $\begin{array}{c}37 \\
22.1 \%\end{array}$ & $\begin{array}{c}35 \\
19.6 \%\end{array}$ & $\begin{array}{c}13 \\
7.2 \%\end{array}$ & $\begin{array}{c}85 \\
48.9 \%\end{array}$ \\
\hline \begin{tabular}{|l|} 
Teaching with \\
new, different \\
methods or \\
modification of \\
teaching aims \\
\end{tabular} & $\begin{array}{c}48 \\
29.2 \%\end{array}$ & $\begin{array}{c}12 \\
6.7 \%\end{array}$ & $\begin{array}{c}20 \\
11.1 \%\end{array}$ & $\begin{array}{c}80 \\
47 \%\end{array}$ \\
\hline $\begin{array}{l}\text { Referral to } \\
\text { Centres for } \\
\text { Differential } \\
\text { Diagnosis, } \\
\text { Diagnosis and } \\
\text { Support } \\
\text { (KEDDY) }\end{array}$ & $\begin{array}{c}5 \\
3.3 \%\end{array}$ & $\begin{array}{c}14 \\
7.8 \%\end{array}$ & $\begin{array}{c}25 \\
13.9 \%\end{array}$ & $\begin{array}{c}44 \\
25 \%\end{array}$ \\
\hline $\begin{array}{l}\text { Referring parents } \\
\text { to specialized } \\
\text { out-of-school } \\
\text { experts }\end{array}$ & $\begin{array}{c}5 \\
3.8 \%\end{array}$ & $\begin{array}{c}13 \\
7.2 \%\end{array}$ & $\begin{array}{c}14 \\
7.8 \%\end{array}$ & $\begin{array}{c}32 \\
18.8 \%\end{array}$ \\
\hline $\begin{array}{l}\text { Seeking support } \\
\text { by KEDDY }\end{array}$ & $\begin{array}{c}0 \\
0.0 \%\end{array}$ & $\begin{array}{c}5 \\
2.7 \%\end{array}$ & $\begin{array}{c}22 \\
12.2 \%\end{array}$ & $\begin{array}{c}27 \\
14.9\end{array}$ \\
\hline $\begin{array}{l}\text { Researching the } \\
\text { relevant literature }\end{array}$ & $\begin{array}{c}0 \\
0 \% \\
\end{array}$ & $\begin{array}{c}4 \\
2.2 \% \\
\end{array}$ & $\begin{array}{c}6 \\
3.3 \% \\
\end{array}$ & $\begin{array}{c}10 \\
5.5 \% \\
\end{array}$ \\
\hline \begin{tabular}{|l|} 
Seeking \\
assistance by \\
out-of-school \\
experts
\end{tabular} & - & - & $\begin{array}{c}2 \\
1.1 \%\end{array}$ & $\begin{array}{c}2 \\
1.1 \%\end{array}$ \\
\hline
\end{tabular}

Hurdles when Dealing with Metacognitive Deficits

Based on the answers of educators and the averages that were derived from the analysis, the hurdles encountered when dealing with metacognitive deficits (Figure 4) are as follows:

1. Lack of specialized knowledge $(\mathrm{N}=181$, mean=4.11, $\mathrm{SD}=0.98$ )

2. Teaching time $(\mathrm{N}=178$, mean $=3.95$, $\mathrm{SD}=0.90)$

3. Analytical teaching scheme $(\mathrm{N}=180$, mean=3.55, $\mathrm{SD}=0.91$ )

4. The degree of achievement of teaching aims $(\mathrm{N}=179$, mean $=3.40, \mathrm{SD}=0.91)$ 
5. Selection of the appropriate teaching methods $(\mathrm{N}=179$, mean $=3.15, \mathrm{SD}=1.02)$

6. Amount of taught curriculum ( $\mathrm{N}=177$, mean $=3.02, \mathrm{SD}=1.08$ )

7. Cooperation with family $(\mathrm{N}=178$, mean $=2.35, \mathrm{SD}=0.80$ )

8. System for assessment of school performance and grades $(\mathrm{N}=174$, mean $=2.31, \mathrm{SD}=0.90)$

Assessment of Metacognitive Skills of Students after the Intervention

Among the educators who responded to the question of "what to do, how to, how often, for what purpose" ( $\mathrm{N}=176$, missing $=7)$, the majority of educators $(\mathrm{N}=116,66 \%)$ implement the assessment of the metacognitive skills of students to a moderate or low degree following the teaching interventions that they make to their students

\section{DiscuSSION}

The fundamental research questions that were posed during the course of this study concerned how middle or high school teachers have the capability to detect and assess the existing level of metacognitive deficits among students with learning difficulties and how they implemented teaching methods in response.

From this study, it was derived that middle and high school educators are aware of the term metacognitive deficits to a moderate degree and at the same time they feel that they are prepared to support students with learning difficulties to a moderate degree. However, there was variation among educators with postgraduate degrees. Additionally, based on the sample's answers, only a small number of educators implement metacognitive strategies to deal with metacognitive deficits among students with learning difficulties who study in middle schools. In this sample, it seems that there is no significant variation between educators with postgraduate degrees and bachelor's degree. It seems that the detection and more notably the provision of teaching support through metacognitive strategies are "uncharted waters" for educators. On the other hand, students with LD have a small set of metacognitive strategies or they are unsure of which strategy to follow. This can lead students to give up their attempts to achieve their aims.

To deal with these crucial issues, educators primarily stated that they do not possess to a satisfactory degree the necessary knowledge to support students with metacognitive deficits and highlight the need for substantial training. From the research data of Mastropieri \& Scruggs (2007), both special and general education teachers expressed their willingness to be trained in differential strategies, on subjects such as special education. Furthermore, according to Austin (2001), a number of educators feel that they have not been sufficiently prepared to effectively support students with special needs. Similarly, in the research of Ftiaka, Michailidou, Tsouris \& Vlami (2005), it is mentioned that a number of educators believe they cannot teach children with special needs as they do not possess special education knowledge.

In general, training, as it is offered in Greece, lacks structure and effectiveness. An exception is the introductory training of educators who are hired by public schools for any work contract duration (permanent or temporary), which is compulsory for everyone, even those who possess a master's or $\mathrm{PhD}$ (Law 3258/2007, articles $40 \& 47)$. Moreover, the training of educators who will participate in co-teaching schemes in special classes is compulsory.

In Greece, general educators used to be able to take a two-year leave in order to be trained in various universities, where training for primary school educators in the subject of special education was offered (this scheme was known as "Didaskaleio") (Ministry of Education, 12567/09-02-2011). This scheme stopped in 2012. Another option for training is the Regional Training Centres (RTC). In Greece, there are 14 training centers but the provided schemes on the subject of special education are restricted. Despite the economic crisis (since 2008) and the economic reformation program known as "Memorandum" (since May 2010) (Mavropalias \& Anastasiou, 2016), an important initiative for the training of educators is the program called "Specialized education support program for the inclusion of students with disabilities and/or special teaching needs." The aim of this initiative was the realization of specialized training support for students with special needs (including students with LD) in general education schools by appropriately trained educational personnel. It is predicted that the training of 3060 primary and middle school educators will take place from 2014 to 2020 (767 per year). Funding for the project in the amount of 40,230,748.76 euros comes from the European Social Fund (ESPA), constituting 85\% of the total cost (Ministry of Finance, 13695/1810-2016). 
As concluded from the current study, the first action to deal with education deficits by educators is to seek assistance from school advisors. In Greece, school advisors possess a master's or $\mathrm{PhD}$ degrees and several years of teaching experience. Their duties include the pedagogical and teaching guidance of educators. Additionally, according to a decision of the Ministry of Education (27922/Г6/2007) educators are supposed to let the school advisor know about learning and behavioral problems faced in their classes that have not been investigated by interventions inside the school. Their role consists of providing guidance for the design of a short-term teaching scheme and also to intervene when a student is deemed to need referral to the Centres for Differential Diagnosis, Diagnosis and Support (KEDDY) for further assessment and support. From relevant research (Efraimidis et al., 2012), it was concluded that general class educators are not adequately aware of the set of laws that define the assessment and interventions procedures for special learning needs, and as they mention, this is due mainly to the fact that the above procedures are not clearly defined. Among the preferred education interventions and modifications of teaching aims for support of students with metacognitive deficits, this was the fourth highest choice. It seems that middle school educators feel to a very limited degree capable of improving the academic skills of their students with LD, as according to the findings of this study, they prefer the child's family to support them with their own means (the second choice) or to seek assistance from one of their school colleagues.

Finally, in the current study it was deduced that most educators (about 90\%) arranged the students' desks in rows, in the traditional Greek way. A consequence of this arrangement is the reduced capabilities of the student with learning difficulties to interact with their classmates. According to Mastropieri et al. (2005), increasing the social involvement and social skills of a child with learning difficulties is an important aim. Hence, it is essential that the child is provided with as many opportunities as possible for interaction with his or her peers (Murawski \& Hughes, 2009). Another possible interpretation of why educators arranged the students' desks in rows is lack of space in classrooms. The "modular" arrangement of desks requires large classrooms.

\section{Limitations AND FUTURE RESEARCH}

In this study we used quantitative analysis of survey questionnaire data. No further research was conducted on teachers' observations that would give us a clearer picture of the ways that metacognitive deficits are addressed. Additionally, no qualitative research using the interview method was conducted that would allow the opinions of educators to be examined in depth. Future studies could examine metacognitive deficits not only in middle schools but also in high schools so that that there is a clear picture of secondary education as a whole. Furthermore, the sample of the research could include not only middle schools in Athens-which is the capital of Greece-but schools in all municipalities. Finally, metacognitive deficit issues in the Greek educational system could be compared to the issues faced in educational systems of other countries

\section{REFERENCES}

[1] Anastasiou, D. (2008). Diagnostic approach of dyslexia: Problems with criteria and identification procedures. Educations and Science, 4, 387-410.

[2] Anderson, J. A., Kutash, K., \& Duchnowski, A. J. (2001). A comparison of the academic progress of students with EBD and students with LD. Journal of Emotional and Behavioral Disorders, 9(2), 106-115.

[3] Austin, V. L. (2001). Teachers' beliefs about co-teaching. Remedial and Special Education, 22, 245-255.

[4] Botsas, G. \& Padeliadu, S. (2003). Goal orientation and reading comprehension strategy use among students with and without reading difficulties. International Journal of Educational Research, 39, 477-495.

[5] Carr, M. \& Kirtz, B. (1991). Teachers' perceptions of their students' metacognition, attributions and self-concept. Educational Psychology, 61(2), 197-206.

[6] Ftiaka E., Michailidou A., Tsouris C. \& Vlami, S. (2005). Assessment of the institution of inclusion of children with special needs in general schools. Primary education. Nicosia: University of Cyprus and Pedagogical Institute.

[7] Garmabi, H. \& Zareian, G. (2016). Metacognitive Strategies Used by High School Students. International Journal of Learning \& Development, 6(1), 61-75.

[8] Law 3258/2007. Articles 40 \& 47. New code of public servants.

[9] Law 3699/2008. Special education and education of people with disability or special educational needs. Athens: FEK 199A/ October 2, 2008.

[10] Law 3879/2010. Development via life-long learning. 
[11] Mastropieri, M. A., \& Scruggs, T. E. (2007). The inclusive classroom: Strategies for effective instruction (3rd ed.). Upper Saddle River, NJ: Pearson Education, Inc.

[12] Mastropieri, M. A., Scruggs, T. E., Graetz, J., Norland, J., Gardizi, W., \& McDuffie, K. (2005). Case studies in co-teaching in the content areas: Successes, failures and challenges. Intervention in School and Clinic, 40, 260-270.

[13] Mavropalias, T. \& Anastasiou, D. (2016). What does the Greek model of parallel support have to say about co-teaching? Teaching and Teacher Education, 60, 224-233.

[14] Ministry of Education. 27922/Г6/2007. Duties of special needs educators.

[15] Ministry of Education, 12567/09-02-2011 Exams for Didaskaleio

[16] Ministry of finance. 13695/18-10-2016. Individual support programme for inclusion of students with special needs.

[17] Murawski, W. W., \& Hughes. C. E. (2009). Response to intervention, collaboration, and coteaching: A logical combination for successful systemic change. Preventing School Failure 53(4), 267-277.

[18] National Research Council. (1998). Preventing reading difficulties in young children. C. E. Snow, M. S. Burns, and P. Griffin (Eds.). Committee on Prevention of Reading Difficulties in Young Children. Washington, DC: National Academy Press.

[19] Panteliadou, S. \& Botsas, G. (2007). Learning difficulties: Basic concepts and characteristics, Athens: Graphima. [In Greek].

[20] Panteliadou, S. (2011). Learning difficulties and education action: what and why. Athens:
Ellinika Ganmmata [In Greek].

[21] Pintrich, P. R. (1999). The role of motivation in promoting and sustaining self-regulated learning. International Journal of Educational Research, 31(6). 459-470.

[22] Polychronopoulou, S. (2012). Children and adolescents with special needs and capabilities. Athens: Self-published. [In Greek].

[23] Rama, S. (2011). Professors' performance for effective teaching. Procedia Social and Behavioral Sciences, 12, 117-121.

[24] Salvaras, J. (2013). Teaching of children with special needs in a typical school. Athens: Grigoris. [In Greek].

[25] Swanson, H. L., Cooney, J. B. \& McNamara, J. K. (2004). Learning disabilities and memory. B. Y. L. Wong (Ed.). Learning about learning disabilities. San Diego, CA: Academic Press.

[26] Tannock, R. (2014). DSM-5 changes in diagnostic criteria for specific learning disabilities (SLD): What are the Implications? http://dyslexiahelp.umich.edu/sites/default/files/ IDA_DSM-5\%20Changes.pdf

[27] Weaver, S.O. (2012). The effect of metacognitive strategies on academic achievement, metacognitive awareness, and satisfaction in an undergraduate online education courses. Doctoral dissertation. University of South Alabama.

\section{AUTHOR'S BIOGRAPHY}

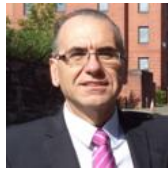

Dr Tryfon Mavropalias, Lecturer, Special Needs Education. University of Western Macedonia/ School of Education/ Department of Primary Education.

Citation: Tryfon, Mavropalias, and Andronidi Charoula. "The Metacognitive Deficits In Middle Schools in Athens." International Journal of Research In Humanities And Social Studies, vol 4, no. 5, 2017, pp. 24-31.

Copyright: () Tryfon, Mavropalias et al. This is an open-access article distributed under the terms of the Creative Commons Attribution License, which permits unrestricted use, distribution, and reproduction in any medium, provided the original author and source are credited. 